\title{
Diversity of arbuscular mycorrhizal fungi in a gypsum mining impacted semiarid area
}

\author{
Adália Cavalcanti do Espírito Santo Mergulhão ${ }^{1,3}$, Hélio Almeida Burity ${ }^{1}$, Bruno Tomio Goto² and Leonor Costa Maia ${ }^{2}$
}

Recebido em 14/01/2010. Aceito em 21/10/2010

\begin{abstract}
RESUMO - (Diversidade de fungos micorrízicos arbusculares em áreas impactadas por mineração gesseira no semiarido). O objetivo deste trabalho foi avaliar o efeito do impacto produzido por mineração de gesso sobre a ocorrência e diversidade de fungos micorrízicos arbusculares (FMA). Amostras de solo foram coletadas nos períodos chuvoso e seco, em quatro áreas de mineração de gesso: caatinga nativa preservada (CN); arredores da mina (AM); área de rejeito (AR) e interface entre o depósito (rejeito) e uma área de caatinga degradada pela mineração (AI). Quarenta e duas espécies de plantas foram identificadas nas áreas; algumas não estavam presentes em ambos os períodos. Trinta e seis táxons de FMA foram identificados: 31 no período chuvoso e 31 no seco, com diferenças na composição de espécies. A atividade de mineração reduziu a diversidade de plantas e de FMA nas três áreas de mineração, comparando com a CN. Baixo índice de similaridade de plantas foi observado entre a CN e as áreas degradadas. Menor similaridade entre espécies de FMA foi observada no período chuvoso e entre a $\mathrm{CN}$ e as áreas impactadas. Glomus intraradices, Glomus sp.1 e Paraglomus occultum foram as espécies mais comumente encontradas, mostrando tolerância às condições edáficas nas áreas impactadas. Estas espécies devem ser testadas em programas de revegetação em áreas similarmente impactadas por mineração de gesso.
\end{abstract}

Palavras chave: área degradada, gesso, micorriza, taxonomia

\begin{abstract}
Diversity of arbuscular mycorrhizal fungi in a gypsum mining impacted semiarid area). The aim of this work was to evaluate the impact of gypsum mining on the occurrence and diversity of arbuscular mycorrhizal fungi (AMF). Soil samples were collected in the rainy and dry periods in four areas of a gypsum mine: native preserved "caatinga" (NC); mine vicinity (MS); reject area (RA); interface between the reject area and an area of "caatinga" degraded by mining (IN). Forty two plant species were identified in these areas; some were not found in both collection periods. Thirty six taxa of AMF were identified: 31 in the rainy and 31 in the dry period, with different species composition. Mining activity reduced diversity of plants and of AMF in the three mining areas when compared to NC. Plant similarity indexes were low between NC and the degraded areas. Similarity among AMF species was lower in the rainy period and between NC and the ones affected by mining. Glomus intraradices, Glomus sp. 1 and Paraglomus occultum were the most common AMF, showing tolerance of edaphic conditions in the impacted areas. These species should be further tested in programs of revegetation of similar gypsum mining degraded areas.
\end{abstract}

Key words: degraded area, gypsum, mycorrhiza, taxonomy

\section{Introduction}

Most of Pernambuco state is located in the semiarid region; of 185 municipalities, 145 are in areas with desertification risk and more than 4,000,000 ha are degraded (Sectma-PE 2006). The Araripe region, in the driest part of the state, is characterized as a gypsum center, with $40 \%$ of the world's reserves and attending $95 \%$ of the national market. The area is under intense anthropic pressure on natural resources. The gypsum extraction process results in degraded areas and gypsum exploitation produces large amounts of waste, inducing detrimental environmental alterations. Moreover, due to inadequate use of natural resources, plant and animal species in these areas are threatened (SectmaPE 2006). Degradation contributes to loss of biodiversity, decrease in soil fertility, and changes in water resources, all collectively causing rapid modification of the landscape (Mendes-Filho 2004). Mining activities also negatively impact diversity of active arbuscular mycorrhizal fungi (AMF), important members of the soil microbiota (Melloni et al. 2003). The mining process includes the removal of plant cover and of the superficial soil layer, which is replaced by another one with few AMF propagules; considering that the mycelial net is destroyed (Jasper et al. 1994), AMF density and diversity is also reduced (White et al. 1989). The presence of AMF is fundamental for regeneration of natural arid ecosystems since these fungi contribute to soil aggregation and to increased tree-species growth in arid and semiarid regions, where plant productivity is limited by low soil fertility (Rao \& Tarafdar 1998). The primary contribution of AMF are nutritional benefits for the host plant, since nutrients of low mobility in the soil, such as $\mathrm{P}$, $\mathrm{Zn}$, and $\mathrm{Cu}$ are made available, increasing plant tolerance to biotic and abiotic factors (Jasper 1994). In semiarid regions inoculation with AMF improves plant productivity by increasing tolerance to dry conditions and availability of mineral nutrients, which limit the establishment of plants in soils where there is mining activity (Marx 2000).

Strategies to enhance soil quality are needed in degraded areas and the use of AMF, producers of a glycoprotein (glomalin) that increases the aggregation of soil particles (Purin \& Rillig 2007), can be beneficial. In the same way, the utilization of native isolates of AMF that assure the establishment of the mycorrhizal association and improve the development of the host plant can be an important contribution for recovering a degraded ecosystem. This goal requires a basic knowledge of richness and abundance of AMF in the area of interest as well as the effect on native plant hosts (Ramos-Zapata \& Guadarrama 2004). There is no agreement regarding an appropriate indicator of biological importance of each species of AMF. An index of abundance

\footnotetext{
1 Instituto Agronômico de Pernambuco, Laboratórios de Genoma e Biologia do Solo, Recife, PE, Brasil

2 Universidade Federal de Pernambuco, Laboratório de Micorrizas, Recife, PE, Brasil

3 Author for correspondence: adalia.mergulhao@ipa.br
} 
and frequency (IAF) of spores has been used to estimate the activity of these fungi in natural environments (Koske et al. 1997).

Around 100 species of AMF have been identified in Brazil (Stürmer \& Siqueira 2006), 52 of which from the semiarid Northeast region (Maia et al. 2006). The first records of AMF were from agricultural ecosystems (Maia \& Trufem 1990) and since then, other investigations in cultivated areas (Weber et al. 2004), impacted areas (Silva et al. 2005; Mergulhão et al.2009), native areas with "caatinga" vegetation and in fragments of Atlantic Forest (Goto \& Maia 2005) have been done, increasing our knowledge of AMF diversity in the region (Maia et al. 2006).

The predominant vegetation of the Brazilian semiarid is known as "caatinga", characterized by hyperxerophytic species, mainly of Cactaceae, Euphorbiaceae and Fabaceae. This biome, which is exclusive to Brazil, presents high loss of habitat, being one of the less protected and most vulnerable (Sampaio \& Araújo 2005) in the semiarid region. Studies in semiarid areas are needed for better knowledge of the diversity and role of local species in ecosystems, especially in those suffering strong anthropic pressure. The occurrence of AMF in impacted ecosystems in Brazil has only recently been investigated (Carrenho et al. 2001; Melloni et al. 2003; Caproni et al. 2003; 2005; Marinho et al. 2004; Silva et al. 2005), without records of mycorrhizal fungi species in gypsum mining areas. Research in these areas is important to provide information about AMF species tolerant to this stress condition, which could be useful in revegetation programs. We investigated the effect of the impact of gypsum mining on the occurrence and diversity of AMF in "caatinga" areas of the Brazilian semiarid region.

\section{Material and methods}

Native and mining impacted caatinga areas located at Araripina, Pernambuco state (7²9'00" S, 40³6'00"W) in Brazil were selected. The region is characterized by a semiarid, mesothermic climate, where the predominant vegetation is hyperxerophytic "caatinga", on red yellow latosol (Cavalcanti \& Lopes 1994). Soil samples were collected in four areas of the mine: (a) native preserved "caatinga" (NC), considered as reference soil; (b) mine vicinity (MS); (c) reject area (RA); (d) interface between the reject deposit area and a degraded "caatinga" area (IN). Samples were taken in each area $\left(1,000 \mathrm{~m}^{2}\right)$ during two periods: rainy (December 2003) and dry (September 2004). In both periods temperature varied from $17.3{ }^{\circ} \mathrm{C}$ and $33.3{ }^{\circ} \mathrm{C}$ and humidity was around $22 \%$. In the rainy period precipitation was $41.9 \mathrm{~mm}$ (October to December) and in the dry period reached only $4.3 \mathrm{~mm}$ (July to September). In each area, ten compound samples of soil were collected ( 5 to $20 \mathrm{~cm}$ deep) from the rhizosphere of plants chosen at random, but at least $100 \mathrm{~m}$ distant from each other. Soil samples were subjected to physical and chemical analyses (Embrapa 1979) at the Instituto Agronômico of Pernambuco (IPA), and also used for AMF studies (Tab. 1).

Spores were extracted from soil by wet sieving (Gerdemann \& Nicolson 1963) and sucrose centrifugation (Jenkins 1964) and mounted with PVLG and PVLG + Melzer's reagent for morphological studies and taxonomic identification using species descriptions from the AMF identification manual by Schenck \& Perez (1990), INVAM homepage (www.invam.caf. wvu.edu), and original papers.

Trap cultures were prepared in plastic pots $(500 \mathrm{~mL})$ with the soil diluted in coarse sand (2:1) and two host plants: Arachis hypogaea L. and Sorghum bicolor (L.) Moench. Three cycles (three months each) of the cultures were maintained at the greenhouse and the plants watered every other day.

The relative density of each AMF species was estimated for each period (rainy and dry), considering the number of spores of a species in that period, as follows: $\mathrm{DR} i=\mathrm{n}_{\mathrm{i}} / \sum \mathrm{n}$, where $\mathrm{DR} i=$ relative density of $i$ species; $\mathrm{n}_{i}=$ total number of spores of species $i$, in $50 \mathrm{~g}$ of soil; $\sum \mathrm{n}=$ sum of the number of spores of all species in $50 \mathrm{~g}$ of soil by determining the percentage. The relative frequency of each AMF species was estimated for all sampling periods, as a proportion of the sum of the frequencies of all species, represented by $\mathrm{Fr}_{i}=\mathrm{F} / \sum \mathrm{f}$, where $\mathrm{Fr}_{i}=$ frequency of relative occurrence of a species $i ; \mathrm{F}_{i}$ $=$ frequency of occurrence of a species $i ; \sum \mathrm{f}=$ sum of frequencies of all species (Brower \& Zar, 1984), by determining the percentage. The index of spore frequency abundance (IAF) was calculated for each AMF species by the sum of the relative frequency ( $\mathrm{Fr}$.) and the relative abundance of the spores from sampling periods (Koske et al. 1997), by determining the percentage, after the three cycles of trap cultures. The species were ordered in four categories: no importance $(\mathrm{IAF}=0)$; low importance $(0<\mathrm{IAF} \leq$ $10)$; moderate importance $(10<\mathrm{IAF} \leq 30)$ and high importance $(\mathrm{IAF}>30)$.

The similarity of plants and AMF species (derived from pot cultures) between the areas was evaluated by the Sorensen index (Brower \& Zar 1984): $\mathrm{S}=2 \mathrm{c} / \mathrm{a}+\mathrm{bx} 100$, where $\mathrm{c}=$ number of species common to both areas ( 1 and 2$) ; a=$ number of species in area $1 ; b=$ number of species in area 2 .

The indexes of diversity and dominance (Hendrix et al. 1995) were calculated for analysis of the communities, considering each soil sample after the three cycles of trap cultures. The index of diversity of ShannonWiener ( $\left.H^{\prime}\right)$ was obtained by the formula: $H^{\prime}=-\sum\left(X_{i} / X_{o}\right) \cdot \log \left(X_{i} / X_{o}\right)$, where $\mathrm{X}_{\mathrm{i}}=$ density of spores of each species, and $\mathrm{X}_{\mathrm{o}}=$ total density of spores from all species. The Simpson index (C) of dominance was calculated by the formula $\mathrm{C}=\sum\left(\mathrm{X}_{\mathrm{i}} / \mathrm{X}_{\mathrm{o}}\right)^{2}$.

A previous test of normality "Shapiro-Wilk Normality Test" (Shapiro $\&$ Wilk 1965) was performed with the data of the diversity and dominance indexes; considering that it was significant, non-parametric tests were later applied. Statistical analysis of the diversity and dominance indexes was obtained by the Mann-Whitney (Differences between the sampling periods) and Kruskal-Wallis (Differences between all areas in each period) non parametric tests, considering 10 samples/treatment. The differences on spore density/AMF species between the sampling periods were analyzed by the Mann-Whitney test (Noether 1983).

\section{Results}

Forty two plant species, belonging to 37 genera from 25 families were found: 27 species in the rainy period and 29 during the dry period. Of these, 14 were present in both periods, 13 exclusive to the rainy period and 15 in the dry period (Tab. 2). Plant diversity was lower in the impacted areas, with difference of up to $69 \%$ in comparison with the native area. Only five species: Ruellia paniculata L., Alternanthera tenella Colla, Ziziphus joazeiro Mart., Croton sp. and the exotic Prosopis juliflora DC. were found in the most degraded area (RA and MS). Fabaceae and Euphorbiaceae were represented by a higher number of species (six and four, respectively).

Regarding the AMF, 36 species were identified, 26 of which in both collection periods. Thirty one species were found in the rainy period and the same number during the dry period (Tab. 3), from which five were exclusive to the rainy period and five to the dry period. From the total number of species, $11(30 \%)$ belonging to Glomus, Acaulospora and Scutellospora were represented by seven species each, Gigaspora by two species and Ambispora, Entrophospora and Paraglomus by only one species. Glomus mosseae, Glomus intraradices, Glomus sp.1 and Paraglomus occultum were the most common species, found in all of the areas 
Table 1. Chemical and physical characteristics of the soil collected in two periods (rainy and dry), in four areas of a gypsum mine, in Araripina, Pernambuco State, Northeast Brazil.

\begin{tabular}{|c|c|c|c|c|c|c|c|c|c|c|c|c|c|c|c|c|c|c|c|}
\hline \multirow{2}{*}{ Areas $^{1}$} & $\mathrm{pH}$ & $\mathrm{P}$ & $\mathrm{C}$ & $\mathrm{Ca}$ & $\mathrm{Mg}$ & $\mathrm{K}$ & $\mathrm{SO}_{4}$ & $\mathrm{CO}_{3}$ & $\mathrm{HCO}_{3}$ & $\mathrm{Fe}$ & $\mathrm{OM}$ & \multicolumn{3}{|c|}{ Textural analysis $(\%)$} & Dap & Dr & $\mathrm{RH}$ & WP & \multirow{2}{*}{ Textural class } \\
\hline & \multicolumn{3}{|c|}{$\mathrm{H}_{2} 0 \mathrm{mg} \cdot \mathrm{dm}^{-3} \mathrm{~g} \cdot \mathrm{Kg}^{-1}$} & \multicolumn{3}{|c|}{ cmolc.dm ${ }^{-3}$} & \multicolumn{3}{|c|}{ meq. $\mathrm{L}^{-1}-$} & $\mathrm{mg} / \mathrm{dm}^{3}$ & $\%$ & Sand & Clay & Silte & \multicolumn{2}{|c|}{$\mathrm{g}^{\prime} \mathrm{cm}^{3}$} & $\%$ & $15 \mathrm{Atm}$ & \\
\hline \multicolumn{20}{|c|}{ Raining period } \\
\hline $\mathrm{NC}$ & 6.28 & 5 & 1.16 & 5.90 & 1.30 & 0.43 & Presence & 0.20 & 1.80 & 12.73 & 2.00 & 67 & 8 & 25 & 1.44 & 2.50 & 1.25 & 4.47 & Sandy Franco \\
\hline IN & 5.72 & 11 & 1.27 & 20.00 & 9.30 & 0.46 & Presence & 0.20 & 0.80 & 52.50 & 2.19 & 26 & 45 & 29 & 1.21 & 2.55 & 6.90 & 20.51 & Clayey \\
\hline MS & 7.64 & 54 & 1.34 & 40.50 & 6.25 & 0.19 & Strong Presence & 0.40 & 1.60 & 0.93 & 2.31 & 22 & 39 & 39 & 1.20 & 2.31 & 8.65 & 24.88 & Clayey Franco \\
\hline RA & 7.65 & 42 & 0.72 & 68.00 & 9.75 & 0.34 & Strong Presence & 0.20 & 1.20 & 0.41 & 1.24 & 27 & 6 & 67 & 1.28 & 2.58 & 7.00 & 18.14 & Silty Franco \\
\hline \multicolumn{20}{|c|}{ Dry period } \\
\hline $\mathrm{NC}$ & 6.43 & 8 & 1.20 & 6.20 & 1.15 & 0.36 & Presence & 0.80 & 5.60 & 13.73 & 2.07 & 74 & 8 & 18 & 1.34 & 2.59 & 0.40 & 4.67 & Sandy Franco \\
\hline IN & 5.72 & 14 & 1.30 & 36.25 & 11.25 & 0.62 & Strong Presence & 0.00 & 0.80 & 79.80 & 2.24 & 14 & 59 & 27 & 1.13 & 2.44 & 8.60 & 30.65 & Clayey \\
\hline MS & 7.52 & 161 & 1.33 & 45.40 & 3.10 & 0.40 & Strong Presence & 0.00 & 1.60 & 0.71 & 2.29 & 22 & 47 & 31 & 1.10 & 2.36 & 6.80 & 26.93 & Clayey Franco \\
\hline RA & 7.56 & 32 & 0.65 & 61.75 & 1.65 & 0.46 & Strong Presence & 0.20 & 2.40 & 0.23 & 1.12 & 37 & 28 & 35 & 1.22 & 2.46 & 6.55 & 8.29 & Silty Franco \\
\hline
\end{tabular}

${ }^{1}(\mathrm{NC})=$ native, preserved "caatinga"; (MS) = mine vicinity; (RA) = reject area; (IN) = interface between the waste deposit and an area of "caatinga" degraded by mining; $\mathrm{OM}=$ organic matter; Dap = Bulk density; Dr= Particle density; $\mathrm{RH}=$ Relative humidity; WP $=$ Wilting point.

Table 2. Plant species in a gypsum mining area, in Araripina, Pernambuco state, Brazil, registered in two periods (rainy and dry).

\begin{tabular}{|c|c|c|c|c|c|c|c|c|}
\hline \multirow{3}{*}{ Family/Species } & \multicolumn{4}{|c|}{ Raining period } & \multicolumn{4}{|c|}{ Dry period } \\
\hline & \multicolumn{8}{|c|}{ Areas $^{1}$} \\
\hline & $\mathrm{NC}$ & MS & RA & IN & $\mathrm{NC}$ & MS & RA & IN \\
\hline \multicolumn{9}{|l|}{ Acanthaceae } \\
\hline Ruellia paniculata $\mathrm{L}$. & & & & & & $\mathrm{X}$ & $\mathrm{X}$ & \\
\hline Dicliptera sp. & & & & & $\mathrm{X}$ & & & \\
\hline \multicolumn{9}{|l|}{ Amaranthaceae } \\
\hline Alternanthera tenella Colla & & & & & & $\mathrm{X}$ & $\mathrm{X}$ & \\
\hline \multicolumn{9}{|l|}{ Anacardiaceae } \\
\hline Myracrodruon urundeuva Fr. Allem. & $\mathrm{X}$ & & & & $\mathrm{X}$ & & & \\
\hline Spondias tuberosa Arruda & $\mathrm{X}$ & & & & $\mathrm{X}$ & & & \\
\hline \multicolumn{9}{|l|}{ Annonaceae } \\
\hline Rollinia leptopetala R.E. Fries & $\mathrm{X}$ & & & & $\mathrm{X}$ & & & \\
\hline \multicolumn{9}{|l|}{ Apocynaceae } \\
\hline Aspidosperma pyrifolium Mart. & $\mathrm{X}$ & & & & & & $\mathrm{X}$ & $\mathrm{X}$ \\
\hline \multicolumn{9}{|l|}{ Asteraceae } \\
\hline Tagetes minuta $\mathrm{L}$. & & & & & & $\mathrm{X}$ & $\mathrm{X}$ & \\
\hline \multicolumn{9}{|l|}{ Bignoniaceae } \\
\hline Arrabidaea corallina (Jacq.) Sandw. & & $\mathrm{X}$ & & & & & & \\
\hline \multicolumn{9}{|l|}{ Boraginaceae } \\
\hline Heliotropium procumbens Mill. & & & & & & & $\mathrm{X}$ & $\mathrm{X}$ \\
\hline \multicolumn{9}{|l|}{ Bromeliaceae } \\
\hline Tillandsia loliacea Mart. ex Schult. f. & & & & & $\mathrm{X}$ & & & \\
\hline \multicolumn{9}{|l|}{ Burseraceae } \\
\hline Commiphora leptophloeos (Mart.) Gillet. & $\mathrm{X}$ & & & & $\mathrm{X}$ & & & \\
\hline \multicolumn{9}{|l|}{ Cactaceae } \\
\hline Pilosocereus sp. & & & & $\mathrm{X}$ & & & & $\mathrm{X}$ \\
\hline \multicolumn{9}{|l|}{ Caricaceae } \\
\hline Jacaratia sp. & $\mathrm{X}$ & & & & $\mathrm{X}$ & & & \\
\hline \multicolumn{9}{|l|}{ Capparaceae } \\
\hline Caparis hastata $\mathrm{L}$. & $\mathrm{X}$ & & & & & & & \\
\hline Caparis flexuosa (L.) L. & $\mathrm{X}$ & & & & & $\mathrm{X}$ & & \\
\hline \multicolumn{9}{|l|}{ Convolvulaceae } \\
\hline Ipomoea sp. & $\mathrm{X}$ & & & & $\mathrm{X}$ & & & \\
\hline Ipomoea phyllomega (Vell.) House & & & & & $\mathrm{X}$ & & & \\
\hline Merremia sp. & & & & & & $\mathrm{X}$ & & \\
\hline \multicolumn{9}{|l|}{ Euphorbiaceae } \\
\hline Croton sonderianus Mull. Arg. & $\mathrm{X}$ & & & & $\mathrm{X}$ & & & \\
\hline Croton $\mathrm{sp}$ & $\mathrm{X}$ & & & $\mathrm{X}$ & $\mathrm{X}$ & $\mathrm{X}$ & & $\mathrm{X}$ \\
\hline Manihot sp. & & & & $\mathrm{X}$ & & & & \\
\hline Jatropha mollissima (Pohl.) Baill. & & $\mathrm{X}$ & & & & & & \\
\hline
\end{tabular}


Table 2. Continuation.

\begin{tabular}{|c|c|c|c|c|c|c|c|c|}
\hline \multirow{3}{*}{ Family/Species } & \multicolumn{4}{|c|}{ Raining period } & \multicolumn{4}{|c|}{ Dry period } \\
\hline & \multicolumn{8}{|c|}{ Areas $^{1}$} \\
\hline & $\mathrm{NC}$ & MS & RA & IN & $\mathrm{NC}$ & MS & RA & IN \\
\hline \multicolumn{9}{|l|}{ Leguminosae Caesalpinoideae } \\
\hline Bauhinia cheilantha Steud. & $\mathrm{X}$ & & & & & & & \\
\hline Cassia trachypus Mart ex Bemth. & & $\mathrm{X}$ & & & & & & \\
\hline \multicolumn{9}{|l|}{ Fabaceae } \\
\hline Parapiptadenia zehntneri (Harms) M.P. Lima & $\mathrm{X}$ & & & & & & & \\
\hline Mimosa tenuiflora (Willd.) Poir. & $\mathrm{X}$ & $\mathrm{X}$ & & & & & & \\
\hline Mimosa ophthalmocentra Mart. Bemth. & $\mathrm{X}$ & & & & & & & \\
\hline Anadenanthera colubrina (Vell.) Brenan. & $\mathrm{X}$ & & & $\mathrm{X}$ & & & & \\
\hline Prosopis juliflora DC. & & $\mathrm{X}$ & $\mathrm{X}$ & $\mathrm{X}$ & & $\mathrm{X}$ & $\mathrm{X}$ & $\mathrm{X}$ \\
\hline Desmanthus virgatus (L.) Willd. & & & & & & $\mathrm{X}$ & & \\
\hline \multicolumn{9}{|l|}{ Leguminosae Papilionoideae } \\
\hline Rhynchosia minima (L.) DC. & & & & & & & & $\mathrm{X}$ \\
\hline Canavalia sp. & & & & & $\mathrm{X}$ & & & \\
\hline \multicolumn{9}{|l|}{ Malphigiaceae } \\
\hline Banisteria crotonifolia A. Juss. & & & & & $\mathrm{X}$ & & & \\
\hline \multicolumn{9}{|l|}{ Malvaceae } \\
\hline Sida sp. & & & & & & $\mathrm{X}$ & & \\
\hline Sida cordifolia $\mathrm{L}$ & & & $\mathrm{X}$ & & & & $\mathrm{X}$ & \\
\hline Sidastrum micranthum (A. St. -Hill.) Fryxell & & & & & & & & $\mathrm{X}$ \\
\hline \multicolumn{9}{|l|}{ Nyctaginaceae } \\
\hline Guapira noxia (Netto) Sundell. & $\mathrm{X}$ & & & & & & & \\
\hline \multicolumn{9}{|l|}{ Rhamnaceae } \\
\hline Zizyphus joazeiro Mart. & & $\mathrm{X}$ & & $\mathrm{X}$ & & $\mathrm{X}$ & & \\
\hline \multicolumn{9}{|l|}{ Sapindaceae } \\
\hline Allophylus quercifolius (Mart.) Radlk. & $\mathrm{X}$ & & & & & & & \\
\hline \multicolumn{9}{|l|}{ Selaginellaceae } \\
\hline Sellaginella convoluta Spring. & & & & & $\mathrm{X}$ & & & \\
\hline \multicolumn{9}{|l|}{ Vitaceae } \\
\hline Cissus simsiana Schult \& Schult & $\mathrm{X}$ & & & & & & & \\
\hline Total & 19 & 6 & 2 & 6 & 14 & 10 & 7 & 7 \\
\hline
\end{tabular}

${ }^{1}(\mathrm{NC})=$ native, preserved "caatinga"; $(\mathrm{MS})=$ mine vicinity; $(\mathrm{RA})=$ reject area; $(\mathrm{IN})=$ interface between the waste deposit and an area of "caatinga" degraded by mining.

investigated in both collecting periods. Glomus etunicatum was also identified in all areas; however its presence was detected in the dry period (Tab. 3), except in the reject area (RA), where a few spores were extracted from the soil during the rainy period.

A high number of spores of $G$. intraradices (807 and 606 spores $50 \mathrm{~g}^{-1}$ soil) and $P$. occultum (110 and 151 spores 50 $\mathrm{g}^{-1}$ soil) were extracted from samples in the mine vicinity (MS), in both collection periods, respectively (Tab. 3). In general, a higher spore density occurred in the dry period (3805 spores $50 \mathrm{~g}^{-1}$ soil) than in the rainy period (1994 spores $50 \mathrm{~g}^{-1}$ soil). The number of spores of $G$. intraradices, $G$. mosseae, Glomus sp.1, and $P$. occultum differed significantly $(P \leq 0.05)$ between the dry and rainy periods. Some species were found only in the dry period (Acaulospora longula, Scutellospora calospora, Scutellospora heterogama, and Gigaspora gigantea), while others were exclusive to the rainy period (Scutellospora biornata, Scutellospora gregaria, and Scutellospora scutata) (Tab. 3).

In the impacted areas, in both collection periods, $G$. intraradices presented higher relative density and frequency of occurrence than the other AMF. During the dry period, $P$. occultum had high relative spore density in all areas (Tab. 4).
In the area of native "caatinga", Acaulospora scrobiculata, Scutellospora aurigloba, Glomus sp.1, Glomus sp.2 and P. occultum presented higher relative density and frequency of occurrence of spores during both periods. In general, high relative frequency of occurrence was observed for $P$. occultum, G. intraradices, G. mosseae, Glomus sp.1 and Glomus sp.2 (Tab. 4), indicating that these species are more adapted than the other AMF species to this specific semiarid environment. Soils with $\mathrm{pH}$ varying from neutral to alkaline, and low organic-matter content (Tab.1) apparently stimulate sporulation and occurrence of these species (Tab. 4) although other factors, such as host plants, soil biota and climate also contribute to selection of AMF in an ecosystem.

Most of the AMF species showed low or null index of abundance and frequency (IAF) and were not found in all areas (Tab. 4). Although a high IAF had been observed for $P$. occultum in all areas, in both collection periods, in the impacted areas the highest IAF were registered for $G$. intraradices, while in the native "caatinga" high IAF were related to A. scrobiculata, S. aurigloba and Glomus sp.2, which indicates the importance of these species in the study areas. Acaulospora rehmii, Ambispora appendicula, S. gregaria, Scutellospora sp. and Glomus macrocarpum 
Table 3. Density of spores ( $50 \mathrm{~g}^{-1}$ soil) of AMF in the soil samples collected in the rainy period (December/2003) and dry period (Sepember/2004) in native and gypsum mining impacted "caatinga" areas in Araripina, Pernambuco state, Brazil, after three multiplication cycles of trap cultures, in a greenhouse.

\begin{tabular}{|c|c|c|c|c|c|c|c|c|}
\hline \multirow{2}{*}{ AMF species } & \multicolumn{2}{|c|}{$\mathrm{NC}$} & \multicolumn{2}{|c|}{ IN } & \multicolumn{2}{|c|}{ MS } & \multicolumn{2}{|c|}{ RA } \\
\hline & Dec/2003 & $\mathrm{Sep} / 2004$ & Dec/2003 & Sep/2004 & Dec/2003 & Sep/2004 & Dec/2003 & Sep/2004 \\
\hline \multicolumn{9}{|l|}{ Acaulosporaceae } \\
\hline Acaulospora sp. & - & - & 2 & 4 & - & - & - & - \\
\hline A. excavata & 1 & 1 & - & - & - & - & - & - \\
\hline A. foveata & 2 & 2 & - & - & - & - & - & - \\
\hline A. longula & - & 2 & - & - & - & - & - & - \\
\hline A. mellea & - & 1 & 2 & 1 & - & 1 & - & 1 \\
\hline A. rehmii & 1 & 4 & - & - & - & - & - & - \\
\hline A. scrobiculata & 49 & 60 & 1 & 1 & 2 & 1 & - & - \\
\hline A. tuberculata & 2 & 3 & - & - & - & - & - & - \\
\hline Entrosphospora infrequens & - & 1 & - & - & 1 & 1 & - & - \\
\hline \multicolumn{9}{|l|}{ Ambisporaceae } \\
\hline Ambispora appendicula & 4 & 1 & - & - & - & - & - & - \\
\hline \multicolumn{9}{|l|}{ Gigasporaceae } \\
\hline Gigaspora gigantea & - & - & - & 1 & - & - & - & - \\
\hline G. margarita & 3 & 1 & - & - & - & - & - & 1 \\
\hline Gigaspora sp. & 1 & - & 3 & 2 & - & - & - & - \\
\hline Scutellospora aurigloba & 33 & 6 & - & - & - & - & - & - \\
\hline S. biornata & - & - & 1 & - & - & - & - & - \\
\hline S. calospora & - & 3 & - & - & - & - & - & - \\
\hline S. gregaria & 15 & - & - & - & - & - & - & - \\
\hline S. heterogama & - & 2 & - & - & - & - & - & - \\
\hline S. pellucida & 2 & - & -2 & 2 & - & - & - & - \\
\hline S. scutata & 2 & - & - & - & - & - & - & - \\
\hline Scutellospora sp. & 8 & 2 & - & 2 & - & - & - & - \\
\hline \multicolumn{9}{|l|}{ Glomeraceae } \\
\hline Glomus ambisporum & 1 & - & - & - & - & - & - & - \\
\hline G. clavisporum & 5 & 2 & - & - & - & & - & - \\
\hline G. coremioides & 4 & - & - & - & - & & - & - \\
\hline G. etunicatum & - & 1 & - & 7 & - & 37 & 10 & 44 \\
\hline G. glomerulatum & 1 & 1 & - & - & - & - & - & - \\
\hline G. halonatum & 1 & 4 & - & - & - & - & - & - \\
\hline G. intraradices & $20^{*}$ & 4 & 35 & $157^{*}$ & 807 & 606 & 584 & 1126 \\
\hline G. macrocarpum & 3 & - & - & 2 & - & - & - & - \\
\hline G. mosseae & 2 & 1 & 7 & $129^{*}$ & 5 & 20 & 10 & 20 \\
\hline G. pallidum & - & - & - & - & - & - & - & 1 \\
\hline G. sinuosum & 1 & 2 & 1 & - & - & 3 & - & - \\
\hline Glomus sp. 1 & 43 & 5 & $26^{*}$ & 4 & 18 & 71 & 2 & $18^{*}$ \\
\hline Glomus sp. 2 & 20 & 84 & - & 5 & - & 4 & 1 & 4 \\
\hline Glomus sp. 3 & - & 18 & - & - & 2 & 5 & - & - \\
\hline \multicolumn{9}{|l|}{ Paraglomeraceae } \\
\hline Paraglomus occultum & 12 & $459^{*}$ & 101 & $432^{*}$ & 110 & $151^{*}$ & 27 & $271^{*}$ \\
\hline Total of spores/period & 236 & 670 & 179 & 749 & 945 & 900 & 634 & 1.486 \\
\hline Total of species/period & 25 & 25 & 10 & 14 & 7 & 11 & 6 & 9 \\
\hline
\end{tabular}

$(\mathrm{NC})=$ native, preserved "caatinga"; $(\mathrm{IN})=$ interface between the waste deposit and an area of "caatinga" degraded by mining; $(\mathrm{MS})=$ mine vicinity; $(\mathrm{RA})=$ reject area. "Significant at 5\% of probability by the Mann-Whitney test between the two collecting periods, in each area. 


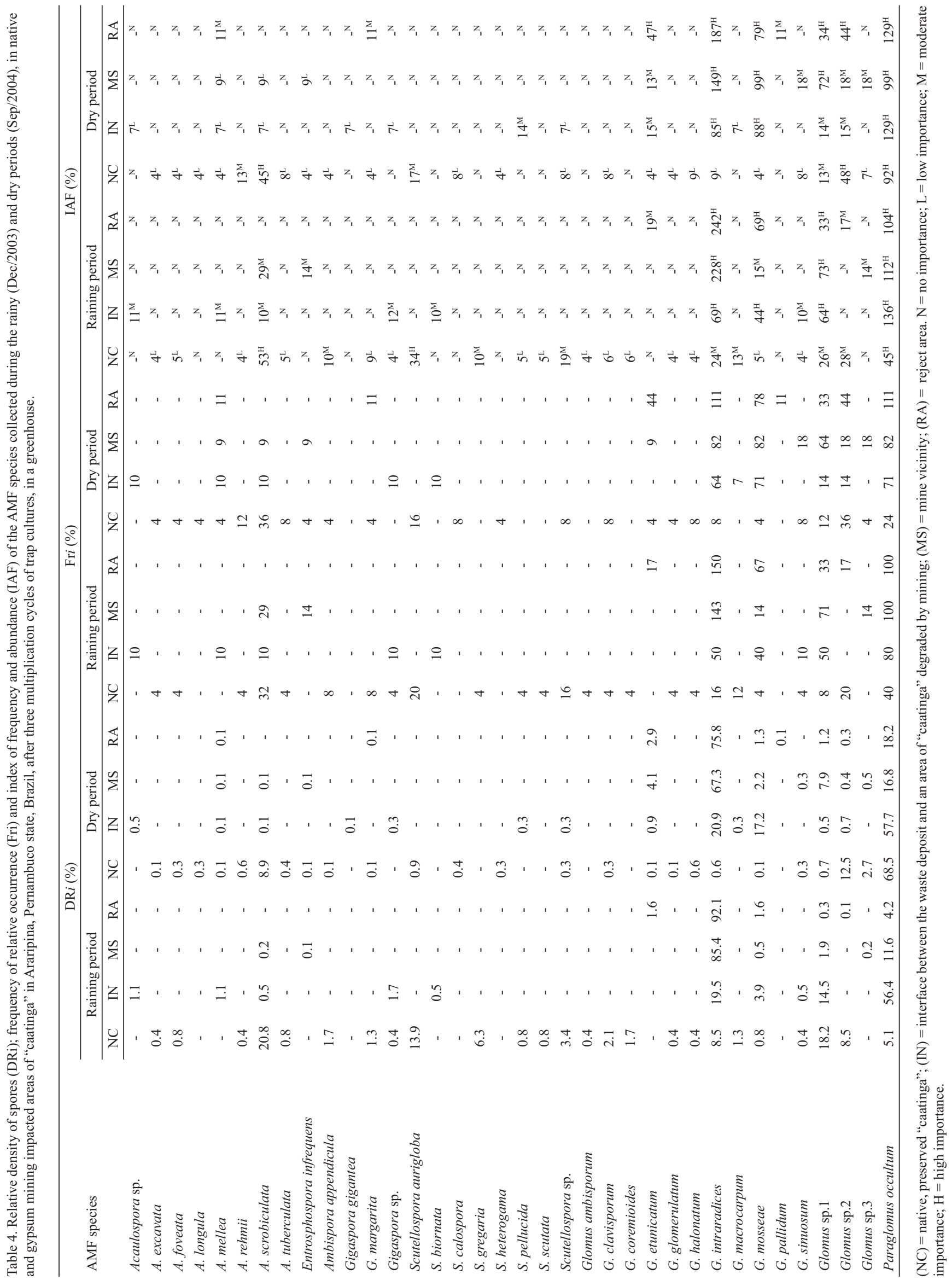


showed moderate importance. Some species showed greater importance in some areas than in others, e.g. G. etunicatum, with high importance only in the reject area, during the dry period (Tab. 4).

The similarity (\%) of plant species between the areas was low $(<16 \%)$ in both periods, with vegetation in the mine vicinity (MS) and interface (IN) more similar between them than the others (Tab. 5). Higher similarity of plant species in the rainy period was observed between IN and MS areas $(33 \%)$, while in the dry period this occurred between the areas RA and MS (47\%). For the AMF, a lower similarity (\%) was also observed between the native "caatinga" area and those with mining activities; between these areas, the highest similarity of AMF occurred between the reject (RA) and the mine vicinity (MS) areas (Tab. 6).

No differences in the index of diversity of AMF were observed between the dry and rainy periods in all study areas, but considering the collecting periods separately, the diversity of AMF was higher in native than in mined areas (Tab. 7). The index of dominance of AMF species was higher in the mining impacted areas than in the native "caatinga" area, during the dry period, with no differences between the areas during the rainy period (Tab. 7).

\section{Discussion}

Mining activities reduced plant and AMF diversity in the study area, a result often reported in other countries, as a consequence of intensive soil disturbance (Kabir et al. 1997). In areas degraded by mineral extraction, the AMF and many plant species that depend on mycorrhization for survival and establishment were reduced or totally eliminated (Allen 1991). Sieverding (1991) showed that fungal adaptation to the soil type and to edaphic conditions are more important for survival than the specificity between the fungus and its host plant. In our study, soil conditions in some of the areas and low water availability due to absence of precipitation in the dry period are factors that certainly contribute to selection and establishment of AMF species.

The reject area (RA) was the most affected, receiving gypsum waste that is deposited on the soil surface and covers the native plants, as also observed in a semiarid area with a copper mine (Silva et al. 2005). Prosopis juliflora an exotic Fabaceae found in the gypsum mining area, is not common among plants of preserved "caatinga" but occurs in impacted areas, showing capability for adaptation in such stress conditions (Silva et al. 2005). Species of Fabaceae and Euphorbiaceae represented by a higher number of species in this paper are cited in revegetation programs in Brazil, and exotic plants such as Acacia mangium Willd (Caproni et al. 2005), Mimosa caesalpinifolia Benth. and Leucaena leucocephala Lam. are used as alternatives for soil restoration (Dias et al. 1995).

The number of AMF species in the study areas was relatively high, with more than 30 taxa, and further studies will probably increase this number with the description of species that may be new to science. The investigations carried out show that the AMF are well distributed in the region. Considering the total number $(=227)$ of known AMF species (www.lrz.de/ sschuessler/amphylo/) and the number of species (52) referred in the semiarid (Maia et al. 2006), an area with high temperatures and low precipitation. Some species of Acaulospora, Gigaspora, Scutellospora and Glomus were not identified at the specific level and many constitute undescribed species. Many Glomus species have been found in semiarid areas, including some impacted by mining (Caproni et al. 2003; Silva et al. 2005; Mergulhão et al. 2009).

Higher levels of $\mathrm{P}, \mathrm{Ca}$ and $\mathrm{pH}$ were found in the mine vicinity (MS) and in the reject (waste deposit) area (RA) than in the preserved site and interface areas (NC and IN). Sixteen species of AMF were exclusively found in the preserved area, characterized by a pH varying from 6.28 to 6.43 and levels of $\mathrm{P}, \mathrm{Ca}$, and $\mathrm{Mg}$ lower than those of the other areas. Eight common species occurred in the native and impacted areas while four were observed only in the impacted areas. In the most impacted areas, $\mathrm{pH}$ increased due to the large deposits of gypsum waste, which certainly affect establishment of AMF species and community structure, considering that $\mathrm{pH}$ was lower in the native "caatinga" and also in the interface area. However, some species such as Glomus sp.1 and $P$. occultum support higher $\mathrm{pH}$, occurring in areas with $\mathrm{pH}>$ 7.0, as observed here and in other investigations (Silva et al. 2005). Spores of G. mosseae were frequently extracted from soils with native "caatinga", in previous studies carried out near the study area (Maia \& Trufem 1990), as well as in other semiarid areas of Northeast Brazil (Maia et al. 2010). G. intraradices and P. occultum were found in bauxite mining areas and also in forest, both in the Amazon region (Marinho et al. 2004), and are commonly found in "caatinga" areas (Maia et al. 2010).

Most of the AMF species were found in both collection periods, but $A$. scrobiculata and S. aurigloba had higher relative density of spores in the rainy than in dry period; the opposite occurred for G. intraradices and P. occultum. Higher relative density of spores of AMF during the dry period was registered in a bauxite mining area in North Brazil (Caproni et al. 2005). The effect of the period of the year on sporulation of AMF has been described (Mehrotra 1998); however it is not possible to say that sporulation is directly affected by seasonality or by the influence of this factor on phenology of the host plant.

The AMF species with low index of abundance and frequency (IAF) might be less adapted to the mining areas. Marinho et al. (2004) registered high IAF for Glomus claroideum and G. macrocarpum in mining degraded areas, and suggested that they should be used as inoculum in similar degraded areas since they are well established in impacted environments. Conversely, AMF with medium to high IAF (A. scrobiculata, Glomus sp.2, G. intraradices, G. mosseae, G. etunicatum, Glomus sp.1, P. occultum and 
Table 5. Similarity (\%) of plant species between preserved and gypsum mining degraded areas in Araripina, Pernambuco state, Brazil, in each collecting period (Rainy $=$ Dec/2003; Dry $=$ Sep/2004).

\begin{tabular}{|c|c|c|c|c|}
\hline \multirow{2}{*}{ Areas $^{1}$} & \multicolumn{4}{|c|}{ Raining period } \\
\hline & $\mathrm{NC}$ & IN & MS & RA \\
\hline $\mathrm{NC}$ & 100 & 16 & 8 & 0 \\
\hline IN & & 100 & 33 & 25 \\
\hline MS & & & 100 & 25 \\
\hline RA & & & & 100 \\
\hline \multirow{2}{*}{ Areas $^{1}$} & \multicolumn{4}{|c|}{ Dry period } \\
\hline & $\mathrm{NC}$ & IN & MS & RA \\
\hline $\mathrm{NC}$ & 100 & 10 & 8 & 0 \\
\hline IN & & 100 & 24 & 42 \\
\hline MS & & & 100 & 47 \\
\hline RA & & & & 100 \\
\hline
\end{tabular}

${ }^{1}(\mathrm{NC})=$ native, preserved "caatinga"; $(\mathrm{IN})=$ interface between the waste deposit and an area of "caatinga" degraded by mining; $(\mathrm{MS})=$ mine vicinity; $(\mathrm{RA})=$ reject area.

Table 6. Similarity (\%) of AMF between preserved and gypsum mining areas in Araripina, Pernambuco state, Brazil, in each collecting period (Rainy $=$ Dec/2003; Dry $=$ Sep/2004), after three multiplication cycles of trap cultures, in a greenhouse.

\begin{tabular}{|c|c|c|c|c|}
\hline \multirow{2}{*}{ Areas $^{1}$} & \multicolumn{4}{|c|}{ Raining period } \\
\hline & $\mathrm{NC}$ & IN & MS & RA \\
\hline $\mathrm{NC}$ & 100 & 40 & 31 & 32 \\
\hline IN & & 100 & 58 & 50 \\
\hline MS & & & 100 & 61 \\
\hline RA & & & & 100 \\
\hline \multirow{2}{*}{ Areas $^{1}$} & \multicolumn{4}{|c|}{ Dry period } \\
\hline & $\mathrm{NC}$ & IN & MS & RA \\
\hline $\mathrm{NC}$ & 100 & 46 & 61 & 47 \\
\hline IN & & 100 & 64 & 60 \\
\hline MS & & & 100 & 70 \\
\hline RA & & & & 100 \\
\hline
\end{tabular}

${ }^{1}(\mathrm{NC})=$ native, preserved "caatinga"; (IN) = interface between the waste deposit and an area of "caatinga" degraded by mining; (MS) = mine vicinity; (RA) $=$ reject area.

Table 7. Diversity (Shannon H') and Dominance indexes (Simpson C) of AMF species in preserved and gypsum mining degraded areas in Araripina, Pernambuco state, in each collecting period (Rainy $=\mathrm{Dec} / 2003$ and Dry $=$ Sep/2004), after three multiplication cycles of trap cultures, in a greenhouse.

\begin{tabular}{lccc}
\hline & \multicolumn{2}{c}{ Dominance index $^{1}$} & \multicolumn{2}{c}{ Diversity index $^{1}$} \\
\cline { 2 - 4 } & Raining period & Dry period & Raining period \\
\hline NC & $1.14 \mathrm{a}$ & $1.41 \mathrm{a}$ & $0.43 \mathrm{a}$ \\
$\mathrm{nN}$ & $0.64 \mathrm{~b}$ & $0.58 \mathrm{~b}$ & $0.60 \mathrm{a}$ \\
MS & $0.51 \mathrm{~b}$ & $0.52 \mathrm{~b}$ & $0.67 \mathrm{a}$ \\
RA & $0.58 \mathrm{~b}$ & $0.55 \mathrm{~b}$ & $0.69 \mathrm{a}$ \\
\hline
\end{tabular}

${ }^{1}$ Values followed by the same letter in the column do not significantly differ by the Kruskal-Wallis test $(\mathrm{P}<0,05)$. No differences in the index of diversity and dominance of species of AMF between the dry and raining periods in all areas by the Mann-Whitney test $(\mathrm{P}<0,05)$. * $(\mathrm{NC})=$ native, preserved "caatinga"; $(\mathrm{IN})=$ interface between the waste deposit and an area of "caatinga" degraded by mining; (MS) = mine vicinity; (RA) = reject area. 
S. aurigloba) might be more adapted to local conditions. If these assumptions are correct, in the investigated areas Glomus sp.1, G. intraradices and P. occultum are the most promising species for field inoculation.

Higher plant similarity (\%) in the impacted areas might be related to the presence of native weeds, as observed mainly between the vicinity and the reject areas. For the AMF, the highest similarity found between the vicinity and reject areas probably was due to the transfer of spores, considering that soil from the mine vicinity was deposited on the reject area. The negative effect of mining activity on diversity of plants and AMF is well known (Silva et al. 2001; 2005; Melloni et al. 2003; Mehrotra 1998). The low levels of similarity of plants and mycorrhizal fungi were observed between the preserved and degraded areas. In the native area the highest volume of roots and the better soil conditions were more suitable for establishment of the AMF species. Diversity of these fungi is affected by number of plant species (Scheublin et al. 2004). The low indexes of diversity $(<0.7)$ found for the degraded areas of this study were similar to those in areas revegetated after extraction of bauxite in North Brazil (Caproni et al. 2003) and were lower than that found in dune areas (0.86) severely degraded (Beena et al. 2000). Analyses of the world occurrence of the AMF community suggest that AMF fungi have different distribution patterns, resulting in high variability of richness and species composition among ecosystems (Öpik et al. 2006).

In the native area, in the dry period, the index dominance of AMF species was less than that registered for the impacted areas, suggesting increase in equitability between the species in areas under environmental impact. This index measures the degree to which a species predominates in a community, due to its size or abundance, and consequently is more sensitive to changes occurring in this species. G. intraradices and $P$. occultum, which presented high sporulation in the gypsum mining areas have high competitiveness in these environments. Comparison of the Shannon's index of diversity of species with that of Simpson's species dominance shows that where species diversity was high, dominance was low. The same was observed in areas revegetated after bauxite extraction (Caproni et al. 2003). In a forest revegetated area in São Paulo state (Southeast Brazil), the index of dominance of AMF (0.17) was considered high (Carrenho et al. 2001), but those found in the areas affected by gypsum mining were higher and similar to that of bauxite mining revegetated areas.

This study revealed that plant and AMF diversity was reduced in soils affected by gypsum mining. The AMF fungi present in impacted areas do not show the same sporulation pattern as in the native area. The data suggest that G. intraradices, Glomus sp.1 and P. occultum have high capacity to tolerate the edaphic conditions of the most impacted areas when compared to the other AMF species. These species should be tested with selected hosts, in future studies or programs for revegetation of mining affected areas.

\section{Acknowledgements}

Thanks to the anonymous referees for the helpful suggestions. The authors also acknowledge the Conselho Nacional de Desenvolvimento Científico e Tecnológico (CNPq) for financial support and a fellowship to L.C. Maia.

\section{References}

Allen, M.F. 1991. The ecology of mycorrhizae. Cambridge, Cambridge University Press.

Beena, K.R.; Raviraja, N.S.; Arun, A.B. \& Sridhar, K.R. 2000. Diversity of arbuscular mycorrhizal fungi on the coastal sand dunes of the west coast of India. Current Science 79: 1459-1466.

Brower, J.E. \& Zar, J.H. 1984. Community similarity. Pp. 226. In: Brower, J.E. \& ZAR, J.H. (eds) Field \& Laboratory Methods for General Ecology. Dubuque, Win C. Brown Publishers.

Caproni, A.L.; Franco, A.A.; Berbara, R. L.L.; Trufem, S.B.; Granha, J.R. D.O. \& Monteiro, A.B. 2003. Ocorrência de fungos micorrízicos arbusculares em áreas revegetadas após mineração de bauxita em Porto Trombetas, Pará. Pesquisa Agropecuária Brasileira 38: 1409-1418.

Caproni, A. L.; Franco, A. A.; Berbara, R. L. L.; Granha, J. R. D. O. \& Marinho, N.F. 2005. Fungos micorrízicos arbusculares em estéril revegetado com Acacia mangium, após mineração de bauxita. Revista Árvore 29: 373-381.

Carrenho, R.; Trufem, S.F.B. \& Bononi, V.L. 2001. Fungos micorrízicos arbusculares em rizosfera de três espécies de fitobiontes instaladas em área de mata ciliar revegetada. Acta Botanica Brasilica 15: 115-124.

Cavalcanti, A.C. \& Lopes, O.F. 1994. Condições edafoclimáticas da Chapada do Araripe e viabilidade de produção sustentável de culturas. Brasília, EMBRAPA - SPI.

Dias, L.E.; Franco, A.A.; Campello, E.; Faria, S.M. \& Silva, E.M. 1995. Leguminosas florestales: aspectos relacionados com su nutrición y uso em la recuperación de suelos degradados. Bosque 16: 121-127.

Embrapa. 1979. Manual de métodos de análise de solo. Rio de Janeiro, Serviço Nacional de Levantamento e Conservação de Solos. SNLCS.

Gerdemann, J.W. \& Nicolson, T.H. 1963. Spores of mycorrhizal Endogone species extracted from soil by wet sieving and decanting. Transactions of the British Mycological Society 46: 235-244.

Goto, B.T. \& Maia, L.C. 2005. Sporocarpic species of arbuscular mycorrhizal fungi (Glomeromycota), with a new report from Brazil. Acta Botanica Brasilica 19: 633-637.

Hendrix, W.; Guo, B.Z. \& An, Z.Q. 1995. Divergence of mycorrhizal fungal communities in crop production systems. Plant and Soil 170: 131-140.

Jasper D.A. 1994. Management of mycorrhizas in revegetation. Pp. 211-219. In: Robson, A.D.; Abbott, L.K. \& Malajczuk, N. (eds). Management of Mycorrhizas in Agriculture, Horticulture and Foresty. Boston, Klewer Academic.

Jasper, D.A.; Abbott, L.K. \& Robson, A.D. 1994. Soil disturbance in native ecosystems- The decline and recovery of infectivity of VA mycorrhizal fungi. Pp 151-155. In: Read, D.J.; Lewis, D.H.; Fitter, A.H. \& Alexander, I.J. (eds.) Mycorrhizas in Ecossystems. Cambridge, CAB International.

Jenkins, W.R. 1964. A rapid centrifugal-flotation technique for separating nematodes from soil. Plant Disease Reporter 48: 692p.

Kabir, Z.; O'halloran, I.P.; Fyles, J.W. \& Hamel, C. 1997. Seasonal changes of arbuscular mycorrhizal fungi as affected by tillage practices and fertilization: hyphal density and mycorrhizal root colonization. Plant and Soil 192: 285-293.

Koske, R.E.; Gemma, J.N. \& Jackson, N. 1997. Mycorrhizal fungi associated with three species of turf grass. Canadian Journal of Botany 75: 320-332.

Maia, L.C. \& Trufem, S.F.B. 1990. Fungos micorrízicos arbusculares em solos cultivados no Estado de Pernambuco, Brasil. Revista Brasileira de Botânica 13: 89-95.

Maia, L.C.; Yano-Melo, A.M. \& Goto, B.T. 2006. Filo Glomeromycota. Pp. 109-126. In: Gusmão, L.F.P. \& Maia, L.C. (orgs.). Diversidade e caracterização dos fungos do semiarido brasileiro. vol. 2. Recife: Associação Plantas do Nordeste - APNE. 
Maia, L.C.; Silva, G.A.; Yano-Melo, A.M. \& Goto, B.T. 2010. Fungos micorrízicos arbusculares no Bioma Caatinga. In: Siqueira, J.O.; Souza, F.A de; Cardoso, E.J.B.N. \& Tsai, S.M. (eds.). Micorrizas: 30 Anos de Pesquisas no Brasil. Lavras, Editora UFLA.

Marinho, N.F.; Caproni, A.L.; Franco, A.A. \& Berbara, R.L.L. 2004. Respostas de Acacia mangium Willd e Sclerolobium paniculatum Vogel a fungos micorrízicos arbusculares nativos provenientes de áreas degradadas pela mineração de bauxita na Amazônia. Acta Botanica Brasilica 18: 141-149.

Marx, D.H. 2000. Stabilizing ecosystems with VAM fungi: significance of VAM fungi in natural plant sucession on disturbed arid and semi-arid lands. PlantHealthCare.com online magazine, Fevereiro. Disponível em http://www.planthealthcare.co.uk/magazine/feb2000. pdf (Acessado em 10/02/2000).

Mehrotra, V.S. 1998. Arbuscular mycorrhizal associations of plants colonizing coal mine spoil in Índia. Journal of Agricultural Science 130: $125-133$.

Melloni, R.; Siqueira, J.O. \& Moreira, F.M.S. 2003. Fungos micorrízicos arbusculares em solos de área de mineração de bauxita em reabilitação. Pesquisa Agropecuária Brasileira 38: 267-276.

Mendes-Filho, P.F. 2004. Potencial de reabilitação do solo de uma área degradada, através da revegetação e do manejo microbiano. 152p. Tese (Doutorado). Piracicaba, Universidade de São Paulo.

Mergulhão, A.C.E.S.; Figueiredo, M.V.B.; Burity, H.A. \& Maia, L.C. 2009. Hospedeiros e ciclos sucessivos de multiplicação afetam a detecção de fungos micorrízicos arbusculares em áreas impactadas por mineração gesseira. Revista Árvore 33: 227-236.

Noether, G.E. 1983. Casualidade, independência e correlação de postos. Pp. 168-171. In: Noether, G.E. (ed) Introdução à estatística: Uma Abordagem não Paramétrica, Rio de Janeiro, Guanabara Dois.

Öpik, M.; Moora, M.; Liira, J. \& Zobel, M. 2006. Composition of rootcolonizing arbuscular mycorrhizal fungal communities in different ecosystems around the globe. Journal of Ecology 94: 778-790.

Purin, S. \& Rillig, M.C. 2007. The arbuscular mycorrhizal fungal protein glomalin: Limitations, progress and a new hypothesis for its function. Pedobiologia 51: 123-130.

Ramos-Zapata, J. \& Guadarrama, P. 2004. Los hongos micorrizógenos arbusculares en la restauración de comunidaes tropicales. Universidad y Ciencia, número especial I: 59-65.
Rao, A.V. \& Tarafdar, J.C. 1998. Significance of microorganisms in a forestation programs in arid zone. Annals of Arid Zone 37: 337-346.

Sampaio, E.V.S.B. \& Araújo, M.S. 2005. Desertificação no nordeste semiárido. Pp. 490-499. In: Nogueira, R.J.M.C.; Araújo, E.L.; Willadino, L.G. \& Cavalcante, U.M.T. (eds) Estresses ambientais: danos e benefícios em plantas. Recife, UFRPE. Imprensa Universitária.

Schenck, N.C. \& Pérez, Y. 1990. Manual for the identification of VA mycorrhizal fungi. 3 ed. Gainesville, Synergistic Publ.

Scheublin, T.R.; Ridgway, K.P.; Young, P.W. \& Van Der Heijden, M.G. A. 2004. Non legumes, Legumes, and Root Nodules Harbor Different Arbuscular Mycorrhizal Fungal Communities. Applied and Environmental Microbiology 70: 6240-6246.

Sectma-PE. 2006. Ações e áreas prioritárias para a conservação da biodiversidade em Pernambuco. In: Atlas da Biodiversidade de Pernambuco. Secretaria de Ciência, Tecnologia e Meio Ambiente de Pernambuco, Recife. http://www.sectema.pe.gov.br/acoes_todos. asp. Acesso em 19/07/2006.

Shapiro, S.S. \& Wilk, M.B. 1965. An analysis of variance test for normality (complete samples). Biometrika 52: 591-611.

Sieverding, E. 1991. Vesicular-arbuscular mycorrhiza management in tropical agrosystems. Technical Cooperation. Eschborn, Federal Republic of Germany.

Silva, G.A.; Maia, L.C.; Silva, F.S.B. \& Lima, P.C.F. 2001. Potencial de infectividade de fungos micorrízicos arbusculares oriundas de áreas de caatinga nativa e degradada por mineração, no Estado da Bahia, Brasil. Revista Brasileira Botânica 24: 135-143.

Silva, A.G.; Trufem, S.F.B.; Saggin-Júnior, O.J. \& Maia, L.C. 2005. Arbuscular mycorrhizal fungi in a semiarid copper mining area in Brazil. Mycorrhiza 15: 47-53.

Stürmer, S.L. \& Siqueira, J.O. 2006. Diversity of Arbuscular Mycorrhizal Fungi in Brazilian Ecosystems. Pp. 206-236. In: Moreira, F.M.S.; Siqueira, J.O. \& Brussaard, L. (orgs). Soil Biodiversity in Amazonian and Other Brazilian Ecosystems: CAB International.

Weber, O.B.; Souza, C.C.M.; Gondin, D.M.F.; Oliveira, F.N.S.; Crisóstomo, L.A.; Caproni, A.L. \& Saggin Jr, O.J. 2004. Inoculação de fungos micorrízicos arbusculares e adubação fosfatada em mudas de cajueiroanão-precoce. Pesquisa Agropecuária Brasileira 39: 477-483.

White, J.A.; Munn, L.C. \& Williams, S.E. 1989. Edaphic and reclamation aspects of vesicular-arbuscular mycorrhizal in Wyoming Red Desert Soils. Soil Science of America Journal 53: 86-90. 